\title{
FACTORS AFFECTING ANAESTHESIA PREFERENCES OF THE GRAVID WOMEN WHO ARE TO DELIVER BY CAESAREAN SECTION
}

\author{
Sahinturk Helin, "Turhan Cakar Sanem, Can Selvi Ozlem, Yilmaz Abbas Ali, Uysalel Asuman \\ Anesthesiology and ICM Department, Ankara University Faculty of Medicine, Ankara, Turkey \\ * Currently working at Anesthesiology and ICM Department, \\ Baskent University Faculty of Medicine, Ankara, Turkey
}

Primljen/Received 05. 01. 2019. god.

Abstract: Objectives: In recent years, a significant increase has been observed in the prevalence of caesarean sections (CS). Although as in many other countries, CS rates in Turkey are higher than the targeted rate. This increase in the prevalence of CS also affects obstetric anaesthesia.

In this study, we investigate the choice of anaesthesia among pregnant women who are scheduled for $\mathrm{CS}$, as well as general anaesthesia and regional anaesthesia rates, the reasons for choosing general anaesthesia or regional anaesthesia, and the factors that affect their choices.

Methods: A questionnaire consisting of 20 questions were applied to pregnant women applying for delivery by elective caesarean operation, between November 2011 to November 2012, in order to study the anaesthesia technique they prefer and the reason behind their preferences.

The questionnaire was applied to pregnant women during the visit, on the day before the operation or while they were waiting in the waiting room before the CS procedure.

Results: Our study revealed that age, gravida, previous type of delivery, previous anaesthesia experience, employment status, monthly income level, educational status, being given information about anaesthesia in advance, the source of information, and being diagnosed with panic disorder were all found to be influential in the decision of which type of anaesthesia to opt for.

Conclusion: We have found out that the reason why pregnant women who have higher educational status, who work and have high level of monthly-income prefer regional anaesthesia method more depends on the fact that they have more information on anaesthesia
Prihvaćen/Accepted 04. 02. 2019. god.

method, they have more common use of the internet and the information they obtain from the people around them is not prejudiced against regional anaesthesia method. We believe that as the education levels rise in the future and the patient population becomes more aware, which will direct them to do more research, their preference rates will change.

Key words: Caesarean, Anaesthesia Preferences, Questionnaire Study.

\section{INTRODUCTION}

In recent years, a significant increase has been observed in the prevalence of caesarean sections (CS). The World Health Organization (WHO) recommends that the rate of CS should be limited to $15 \%(1,2)$, although as in many other countries, CS rates in Turkey are higher than the targeted rate. According to 2016 data published by the Turkish Statistical Institute, the CS delivery rate in Turkey was reported to be $21 \%$ in 2002, which increased to $51 \%$ in 2014 and $53 \%$ in 2015 (3). This increase in the prevalence of CS also affects obstetric anaesthesia, as a highly requested sub-branch of anaesthesiology that is reported to provide satisfactory results. The common acceptability and use of regional anaesthesia for childbirth have raised the importance of obstetric anesthetics in the field of anesthetic applications (4).

In this study, we aimed to investigate the choice of anaesthesia among pregnant women who are scheduled for CS, as well as general anaesthesia and regional anaesthesia rates, the reasons for choosing general anaesthesia or regional anaesthesia, and the factors that affect their choices. 


\section{MATERIAL AND METHODS}

This study was registered at clinical trials.gov. (Registration number: NCT02026284). After obtaining Institutional Ethics Committee approval and written informed patient consent, a total of 750 pregnant women scheduled to undergo elective CS between November 2011 and November 2012 were included in this study, and were asked to fill out a questionnaire investigating the anaesthesia choice and the reasons that affected their choices. The pregnant women who agreed to take part and were included in this study were informed about the questionnaire, and both verbal and written approval was obtained. The questions were asked by the anaesthesiologist, and the patients' answers were recorded by the same physician. The women were informed that they were not obliged to answer every question, and could choose to "pass" if they did not want to answer, and also that they could discontinue the questionnaire whenever they wanted.

The questionnaire was applied to 26-week to 40 -week pregnant women during the visit, on the day before the operation or while they were waiting in the waiting room before the CS procedure. Patients who underwent emergency surgery, patients with communication problems, patients who lacked the mental capacity to answer the questions, and patients who did not want to take part were excluded from the study. Twenty questions included in the questionnaire, which are given in Appendix 1, were asked verbally by the anaesthesiologist.

The first four questions in the questionnaire were designed to determine the demographic characteristics of the respondent, which inquired about the age, obstetric anamnesis (gravida, parity, the number of live births, abortion and curettage) and gestational week, respectively. Women within the high-risk pregnancy age ranges, being younger than 20 years of age and over 35 years of age, were grouped together $(5,6)$. The respondents were asked about their previous types of delivery, the number of normal deliveries (if any) and the number of CS deliveries. They were asked further whether their previous delivery experiences had affected their choice of anaesthesia, and the respondents who gave an affirmative answer were asked how their choices had been affected. The following question was about the type of anaesthesia chosen in any previous deliveries, and how the experience had affected the current choice of anaesthesia. The next three questions garnered information on the respondents' employment status (employed, unemployed, housewife), monthly income (grouped as TRY 500-1000, TRY 1000-2000, TRY 2000-4000 and TRY 4000 and above) and education level (uneducated, primary school graduate, high school graduate, university graduate). Then, they were asked that whether they had been informed about the optional delivery and anaesthesia methods before the operation. Patients who were thought to be informed before the delivery were asked who had informed them, or how they had been informed. A question was asked that included 13 sub-items listing the factors that affected the patients' choice of anaesthesia, their previous anaesthesia experiences, their feelings about previous anaesthesia experiences (whether they satisfied or not), the reasons related to the baby (desire to see the baby immediately after delivery, and the desire to initiate breastfeeding earlier), and their concerns about the anaesthesia method in relation to their choice of general or regional anaesthesia, and their reasons for choosing accordingly. The patients were also asked whether anyone had influenced their anaesthesia choice, or if anyone had made the decision on their behalf, with an affirmative answer being followed by an additional question related to who had made the decision. The final six questions of the questionnaire were prepared considering the opinions and recommendations of the psychiatry clinic and inquired of the respondents whether they suffered from any underlying psychiatric disorders, such as anxiety or panic attacks. Respondents were asked further whether they had any attacks accompanied by palpitations lasting about 10 minutes, shortness of breath, shivering, sweating, high blood pressure, discomfort, anxiety, fear and concerns from time to time. They were then asked whether they had applied for psychiatric assistance as a result of such complaints and whether they had been diagnosed with any anxiety disorder (i.e. panic disorder or generalized anxiety disorder) in the past. In cases where the patient was observed to have an anxiety disorder, regardless of whether or not a diagnosis had been made, it was asked that whether these negative experiences had affected the choice of anaesthesia. In the last two questions, it was asked that whether the patient had suffered any involuntary experiences that have harmed bodily integrity (sexual abuse/harassment), and if the answer was in the affirmative, it was asked that whether this experience influenced their choice of anaesthesia. For this part of the questionnaire, it was ensured that the patient was able to answer this question when she was alone.

The patients were given no guidance while the questions were being asked. It was stated that their choice of anaesthesia would be applied, as long as there were no conditions precluding the chosen anaesthesia, such as systemic disease, upper respiratory tract infection or impaired bleeding profile. In cases where a medical problem may exist, the most appropriate method of anaesthesia would be used for the health of both the mother and baby. 
The SPSS 15.0 package program was used for the evaluation of the statistical data obtained from the questionnaire, which was prepared to evaluate the choices of anaesthesia and related factors. No normality tests were applied, and non-parametric test methods were chosen. A Chi-square or Fisher's exact test was used to test the distribution of categorical variables between the groups, while continuous variables were analysed with Mann-Whitney U or Kruskal Wallis variance analysis tests to determine the differences between groups. Continuous variables were expressed as a median (Minimum-Maximum), and categorical variables were expressed as frequency distributions and percentages in the summary of the results. For the same purpose, graphs were created using percentages and frequencies. A p-value of $<0.05$ was considered statistically significant.

\section{RESULTS}

The respondents were divided into three age groups: $<20$ years of age, which is considered as a risky age group for pregnancy; 21-34, which is considered the ideal age range for pregnancy; and 35-44. The majority of respondents were found to be in the 21-34 year age range $(78.3 \%)$. While the gravida rates of the majority of patients $(39.5 \%)$ were determined as 2 , the parity rate was determined as $0(45.9 \%)$.

Of the participants included in this study, 55.9\% were unemployed, while education levels were defined in four groups, being uneducated, primary school graduate, high school graduate and university graduate. Considering the level of education of the patients included in our study, $0.04 \%$ were uneducated, $27.9 \%$ were primary school graduates, $28.8 \%$ were high school graduates, and $42.9 \%$ were university graduates. When the monthly income levels of the respondents were asked, $23.6 \%$ of the patients were found to be in the TL $500-1,000$ income group, $32.8 \%$ in the TL 1,000-2,000 income group, $9.3 \%$ in the TL 2,000-4,000 income group and $34.3 \%$ in the $>$ TL 4,000 income group.

The socio-demographic characteristics of the women who participated in this study are presented in Table 1.

When asked whether they had been informed about different delivery and anaesthesia methods, the pati-

Table1. Demographic characteristics of the pregnant women

\begin{tabular}{|c|c|c|c|}
\hline & & $\mathbf{n}$ & $\%$ \\
\hline Age of the mother & $\begin{array}{c}<20 \text { years old } \\
21-34 \\
35-44\end{array}$ & $\begin{array}{c}25 \\
587 \\
138\end{array}$ & $\begin{array}{c}3.3 \\
78.3 \\
18.4\end{array}$ \\
\hline Gravida & $\begin{array}{l}1 \\
2 \\
3\end{array}$ & $\begin{array}{l}267 \\
296 \\
104\end{array}$ & $\begin{array}{l}35.6 \\
39.5 \\
13.9\end{array}$ \\
\hline Parity & $\begin{array}{l}\text { Nullipara } \\
\text { Multipara }\end{array}$ & $\begin{array}{l}344 \\
406\end{array}$ & $\begin{array}{l}45.9 \\
54.1\end{array}$ \\
\hline Type of previous delivery & $\begin{array}{l}\text { First child } \\
\text { NVD } \\
\text { C/S } \\
\text { NVD+C/S }\end{array}$ & $\begin{array}{c}339 \\
84 \\
310 \\
17\end{array}$ & $\begin{array}{c}45.2 \\
11.2 \\
41.3 \\
2.3\end{array}$ \\
\hline Previous anaesthesia type & $\begin{array}{c}\text { No anaesthesia experience } \\
\text { RA } \\
\text { GA } \\
\text { RA+GA }\end{array}$ & $\begin{array}{c}421 \\
198 \\
116 \\
15\end{array}$ & $\begin{array}{c}56.1 \\
26.4 \\
15.5 \\
2\end{array}$ \\
\hline Employment status & $\begin{array}{c}\text { Employed } \\
\text { Unemployed }\end{array}$ & $\begin{array}{l}331 \\
419\end{array}$ & $\begin{array}{l}44.1 \\
55.9\end{array}$ \\
\hline Level of monthly income & $\begin{array}{c}\text { TRY500-1000 } \\
\text { TRY1000-2000 } \\
\text { TRY2000-4000 } \\
>\text { TRY4,000 }\end{array}$ & $\begin{array}{c}177 \\
246 \\
70 \\
257\end{array}$ & $\begin{array}{c}23.6 \\
32.8 \\
9.3 \\
34.3\end{array}$ \\
\hline Educational status & $\begin{array}{c}\text { Uneducated } \\
\text { PrimarySchool } \\
\text { High-School } \\
\text { University }\end{array}$ & $\begin{array}{c}3 \\
209 \\
216 \\
322\end{array}$ & $\begin{array}{c}0.4 \\
27.9 \\
28.8 \\
42.9\end{array}$ \\
\hline
\end{tabular}


ents who had been informed were asked who it was that had informed them. Of the 750 women, 438 women $(58.4 \%)$ stated that they had not been informed about the different delivery and anaesthesia options, whereas 312 women (41.6\%) stated that they had been informed, and $46 \%$ of those who had been informed reported being informed by the anaesthesiologist.

The respondents were asked which anaesthesia method they would choose in the absence of problems that would prevent their free choice of anaesthesia, to which $52.3 \%$ stated a preference for regional anaesthesia and $47.7 \%$ preferred general anaesthesia $(\mathrm{p}<0.05)$ (Figure 1).

The factors that affected their choice between regional and general anaesthesia were asked under 14 items. Of the 392 patients who opted for regional anaesthesia, $186(47.4 \%)$ said that their choice was based on their desire to see their baby immediately after the birth. The most common reason for choosing general anaesthesia was that the respondent did not want to see or remember anything. Of the 348 patients who stated a preference for general anaesthesia, 112 (32.1\%) reported preferring this method for the above-mentioned reason (Figure 2 and 3 ).

Patients in the $<20$ age group mostly opted for general anaesthesia, whereas the regional anaesthesia method was preferred in the other groups. Patients in these three groups preferred regional anaesthesia $28 \%$, $53,5 \%, 51,4 \%$ respectively $(\mathrm{p}<0,05)$.

When patients were evaluated according to gravida; $75 \%$ of patients in gravida 0 group, $56,6 \%$ of patients in gravida 1 group, $52 \%$ of patients in gravida 2 group, 50\% of patients in gravida 3-4 group, $29 \%$ of patients in gravida 5 group preferred the regional anaesthesia method. When all gravida categories were evaluated, there was a significant difference between anaesthesia preference distributions $(\mathrm{p}<0,05)$.

Participants in the study were divided into 4 groups according to the previous birth pattern. Patients were not delivered, had normal vaginal delivery, deliv-

\section{ANAESTHESIA PREFERENCES}

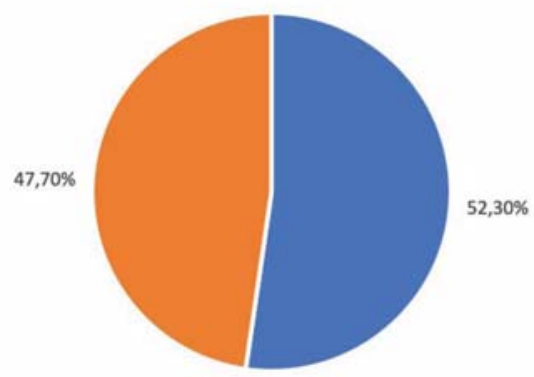

- Regional Anesthesia "General Anesthesia

Figure 1. Anaesthesia preferences

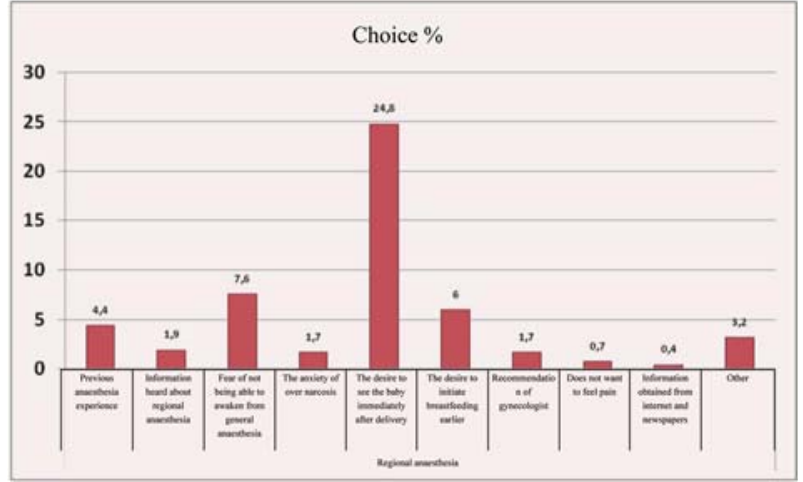

Figure 2. Reasons for choosing regional anaesthesia

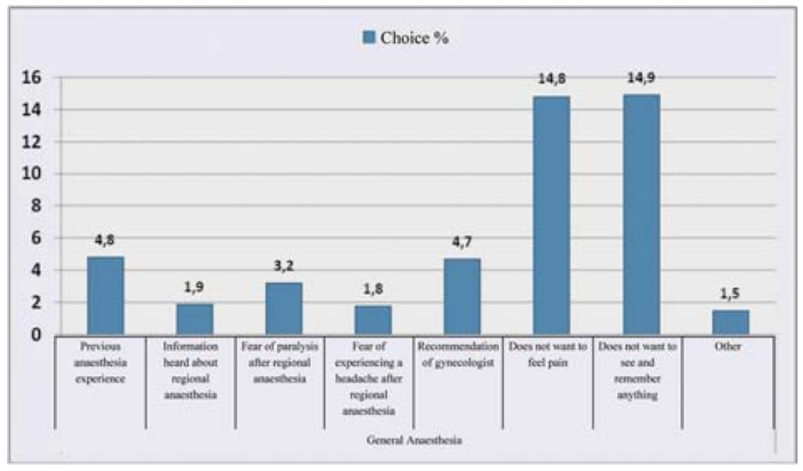

Figure 3. Reasons for choosing general anaesthesia

ered caesarean section, and were classified as having both normal birth and caesarean delivery experience. When patients' anaesthesia choices were asked concerning the previous mode of delivery, the regional anaesthesia method was observed to be higher in the group of patients with no previous delivery experience $(58,1 \%$ vs $41,9 \%)$, whereas the regional and general anaesthesia methods were observed to be preferred at similar rates in the other groups $(45,2 \%$ vs $54,8 \%$, $48,7 \%$ vs $51,3 \%, 35,3 \%$ vs $64,7 \%$ respectively). The general anaesthesia method was preferred more in the group of patients who had previously undergone a normal birth or a caesarean section than in the group of patients with no previous delivery $(p=0.02)$.

The patients in the study were divided into 4 groups according to the previous anaesthesia pattern. They were classified as having no experience of anaesthesia, having regional anaesthesia experience, having general anaesthesia experience, and having both regional anaesthesia and general anaesthesia experience. Of the patients with no anaesthesia experience, $55.6 \%$ of the patients preferred the regional anaesthesia method, whereas $44.4 \%$ were observed to prefer the general anaesthesia method. Of the patients who had regional anaesthesia experience in the past, $36.9 \%$ preferred the regional anaesthesia method, whereas $63.1 \%$ were observed to prefer the general anaesthesia method. Of the patients who had general anaesthesia experience in the past, 68,1\% preferred regional anaesthesia whereas $31,9 \%$ preferred 
Table 2. Factors affecting the preference for anesthesia [n (\%)]

\begin{tabular}{|c|c|c|c|}
\hline & $\begin{array}{c}\text { Regional } \\
\text { Anesthesia } \\
(\mathrm{n}, \%)\end{array}$ & $\begin{array}{c}\text { General } \\
\text { Anesthesia } \\
(\mathrm{n}, \%)\end{array}$ & $p$ \\
\hline \multicolumn{3}{|l|}{ Age groups } & \multirow{4}{*}{$<0.01$} \\
\hline$<20$ age & $7(28 \%)$ & $18(72 \%)$ & \\
\hline 21-34 age & $314(53,5)$ & $273(46,5 \%)$ & \\
\hline $35-44$ age & $71(51,4 \%)$ & $67(48,6 \%)$ & \\
\hline \multicolumn{3}{|l|}{ Gravida } & \multirow{6}{*}{$<0.05$} \\
\hline 0 & $3(75 \%)$ & $1(25 \%)$ & \\
\hline 1 & $151(56.6 \%)$ & $116(43.4)$ & \\
\hline 2 & $154(52 \%)$ & $142(48 \%)$ & \\
\hline $3-4$ & $78(50 \%)$ & $78(50 \%)$ & \\
\hline$\geq 5$ & $8(29 \%)$ & $19(71 \%)$ & \\
\hline \multicolumn{3}{|l|}{ Previous type of delivery } & \multirow{5}{*}{0.02} \\
\hline None & $197(58,1 \%)$ & $142(41,9 \%)$ & \\
\hline Normal vaginal delivery & $38(45,2 \%)$ & $46(54,8 \%)$ & \\
\hline Cesarean section (CS) & $151(48,7 \%)$ & $159(51,3 \%)$ & \\
\hline Normal vaginal delivery $+\mathrm{CS}$ & $6(35,3 \%)$ & $11(64,7 \%)$ & \\
\hline \multicolumn{3}{|l|}{ Previous anesthesia experience } & \multirow{5}{*}{$<0.01$} \\
\hline No experience & $234(55.6 \%)$ & $187(44.4 \%)$ & \\
\hline Regional anesthesia (RA) experience & $73(36.9 \%)$ & $125(63.1 \%)$ & \\
\hline General anesthesia (GA) experience & $79(68,1 \%)$ & $37(31,9 \%)$ & \\
\hline $\mathrm{RA}+\mathrm{GA}$ & $6(42.9 \%)$ & $9(57.1 \%)$ & \\
\hline \multicolumn{3}{|l|}{ Employment status } & \multirow{3}{*}{$<0.01$} \\
\hline Unemployed & $182(43.4 \%)$ & $237(56.6 \%)$ & \\
\hline Employee & $210(63.4 \%)$ & $121(36.6 \%)$ & \\
\hline \multicolumn{3}{|l|}{ Monthly income level } & \multirow{5}{*}{$<0.01$} \\
\hline $500-1000 \mathrm{TL}$ & $78(44.1 \%)$ & $99(55.9 \%)$ & \\
\hline 1000-2000 TL & $101(41.2 \%)$ & $145(58.8 \%)$ & \\
\hline $2000-4000 \mathrm{TL}$ & $39(55.9 \%)$ & $31(44.1 \%)$ & \\
\hline$>4000 \mathrm{TL}$ & $171(66.5 \%)$ & $86(33.5 \%)$ & \\
\hline \multicolumn{3}{|l|}{ Educational status } & \multirow{5}{*}{$<0.01$} \\
\hline Uneducated & $1(33.3 \%)$ & $2(66.7 \%)$ & \\
\hline Primary school graduate & $71(33.8 \%)$ & $138(66.2 \%)$ & \\
\hline High school graduate & $98(45.4 \%)$ & $118(54.6 \%)$ & \\
\hline University graduate & $214(66.5 \%)$ & $108(33.5 \%)$ & \\
\hline \multicolumn{3}{|c|}{ Being given information about anesthesia in advance } & \multirow{3}{*}{$<0.01$} \\
\hline Not been informed & $188(42.9 \%)$ & $250(57.1 \%)$ & \\
\hline Been informed & $204(65.4 \%)$ & $108(34.6 \%)$ & \\
\hline \multicolumn{3}{|l|}{ The source of information } & \multirow{5}{*}{$<0.05$} \\
\hline Anesthesiologist & $114(73.1 \%)$ & $42(26.9 \%)$ & \\
\hline Internet-Newspaper & $61(68.5 \%)$ & $28(31.5 \%)$ & \\
\hline Gynecologist & $27(50.9 \%)$ & $26(49.1 \%)$ & \\
\hline Friends & $19(51.4 \%)$ & $18(48.6 \%)$ & \\
\hline Being diagnosed with panic disorder & $13(18.3 \%)$ & $58(81.7 \%)$ & $<0.01$ \\
\hline
\end{tabular}


the general anaesthesia. Of the patients who tried both methods, $42.9 \%$ preferred regional anaesthesia and $57.1 \%$ preferred general anaesthesia method. When all patient groups were evaluated, there was a statistically significant difference between the preference distributions of previous anaesthesia type and anaesthesia met$\operatorname{hod}(\mathrm{p}<0,01)$.

It was determined that $44.1 \%$ of the respondents were in the employed group while $55.9 \%$ were in the unemployed group. While $63.4 \%$ of the employed pregnant women preferred the regional anaesthesia method, this rate was $43.4 \%$ in the unemployed group $(\mathrm{p}<0,01)$.

As the income level of patients increased, the preference rate of regional anaesthesia increased. The group with the highest preference for regional anaesthesia was the group with the highest income level $(22,8 \%)$. The relationship between monthly income level of patients and preference of anaesthesia was statistically significant $(\mathrm{p}<0.01)$.

The general anaesthesia method was observed to be preferred at a high rate of $66.7 \%$ in the uneducated group, $66.2 \%$ in the primary school graduate group and $54.6 \%$ in the high school graduate group. In the university graduate group, $66.5 \%$ of the respondents were found to prefer regional anaesthesia $(\mathrm{p}<0,01)$.

The respondents were asked about any sexual abuse or harassment that they were subjected to that may have damaged their physical integrity. The intention in this regard was to investigate whether such negative experiences were influential in the choice of anaesthesia type. Only three of the respondents admitted to having had such experiences in the past, and one stated that it had affected here the choice of anaesthesia.

Our study revealed that age, gravida, previous type of delivery, previous anaesthesia experience, employment status, monthly income level, educational status, being given information about anaesthesia in advance, the source of information, and being diagnosed with panic disorder were all found to be influential in the decision of which type of anaesthesia to opt for $(\mathrm{p}<0.05)$ (Table 2).

\section{DISCUSSION}

Many factors may affect the choice of anaesthesia type as some of these can be modified during the pregnancy process, or even on the operating table. Our findings revealed that age, gravida, previous type of delivery, previous anaesthesia experience, employment status, monthly income level, educational status, and preoperative information related to anaesthesia and its source and presence of panic disorder all had significant effect on anaesthesia choice. Although with a little difference, most of our patients preferred regional anaesthesia (RA) to general anaesthesia (GA).

Our results are compatible with similar studies and showed that RA gained more popularity with the increasing knowledge in time. Kocamanoğlu et al. (7) found that rate of regional anaesthesia in $\mathrm{C} / \mathrm{S}$ increased from $3 \%$ to $26.9 \%$ in five years which was attributed to increased experience and facilitated use of regional anaesthesia. Gülha\} et al. (8) found regional anaesthesia as the choice of technique in a rate of $74 \%$, but this study did not analyse the choice of the patient, but the technique used for $\mathrm{C} / \mathrm{S}$.

Age and level of education were the main predictors for the choice of anaesthesia. Patients aged below 20 , mostly preferred general anaesthesia, probably based on concerns related to regional anaesthesia and birth. The respondents in this age group were mainly unemployed, primary school graduates which might be effective in their choice. Whereas pregnant women with high education level and in employed group, and women with easier access to information, choose regional aesthesia more. As gravida increased, we observed that patients were more likely to prefer general anaesthesia, which could be attributed to the thought that it would be a more comfortable and painless method than regional anaesthesia.

Patients with previous birth experiences preferred general anaesthesia more than the patients with no previous delivery experience and this can be attributed to the fears and concerns related to previous birth experiences. Patients with no birth experience had no concerns about themselves since they had had no negative experiences in this regard. Therefore, they focused on baby more and preferred regional anaesthesia.

It was observed that anaesthesia method in the previous births affected the choices oppositely. Patients with no anaesthesia experience and patients with previous GA experience preferred RA more than GA.The will of the patients to be conscious when they first saw their baby, and the negative experiences of GA such as nausea and vomiting lead patients to prefer RA. We believe that patients with no anaesthesia experience in the past tend to opt for RA because they are less concerned about being awake and lack the experience of both methods. Also, patients with previous anaesthesia experience tended to opt for the opposite of the previous method because of the dissatisfaction.

GA was more popular in unemployed group than the employed group $(56,6 \%$ vs $36,6 \%)$, which can be attributed to the level of education and access to information. This result supports the effect of income on the RA preference. Büyükbayrak et al. (9) showed that education level, employment status and income have no effect on choice for type of delivery. But we observed 
that presence of these parameters leads RA as anaesthesia type. Furthermore, they want their babies to be affected as less as possible by aesthetic drugs and want to see their babies after birth and begin breastfeeding.

In our study, regional anaesthesia was preferred more as if the patient required information about the technique. Kocamanoglu et al found $81.8 \%$ of obstetricians preferred general anaesthesia due to inadequate muscle relaxation, difficulties with position and delays, whereas only $15 \%$ of the anaesthetists opted for general anaesthesia (7). If the surgeon has prejudices against regional anaesthesia, this situation is reflected in the pregnant women who are being followed for nine months. However, in recent years, surgeons have tended to be less resistant to regional anaesthesia. Regional anaesthesia was observed to be more popular among women who have gained information from an anaesthesiologist, or even from internet (10). We think that obtaining information from a person with technical knowledge who has no prejudices about the method and obtaining information from a place in which all the details of the subject are available, like the internet, lead to a lifting of prejudices against and fear of regional anaesthesia methods.

Bukar et al. reported that general anaesthesia was preferred more than regional anaesthesia $(70.1 \%$ vs $29.9 \%$ ) for $\mathrm{C} / \mathrm{S}$ (11). This was reported to be related to the anxiety and fear of being awake. In Bukar's study, reasons, such as not wanting to feel pain and to see or remember anything, which were among the rare reasons in the relevant literature, were found to be the most common reason behind the choice of general anaesthesia in our study. Pain is a subjective experience affected by socio-cultural factors, psychosocial factors, and biological factors (12), which plays a major role in anaesthesia choices of pregnant women in our study. In Bukar's study, women chose regional anaesthesia because they wanted to know what was happening, or they were afraid of not being able to wake up after the operation. However, in our study, all the patients chose regional anaesthesia because they wanted to see their babies immediately after birth. We believe that the difference between the results of Bukar et al. and our study is related to the different employment statuses of the two groups. In our study $44.1 \%$ of the respondents were in the employed group, compared to $16.5 \%$ in the study of Bukar et al.

Birth anxiety is associated with various factors, such as age, nulliparity, previous psychological problems and history of abuse $(13,14)$. Anxieties related to childbirth may manifest different aspects. It has been reported that $20 \%$ of the pregnant women have a fear of childbirth and $10 \%$ have severe fear of childbirth. Fear of pain, fear of being incapable of giving birth and fear of death are the most common causes of fear of childbirth (14). In our study 71 of 750 pregnant women $(9.5 \%)$ had been diagnosed with panic disorder. A significant difference was observed in the choice of anaesthesia among the patients who were diagnosed with a panic disorder. Pregnant women who were diagnosed with panic disorders prefer general anaesthesia, which we believe was based on the desire to avoid the anxiety of being conscious during surgery, the fear of feeling pain and concerns about remembering this experience in the future, which they thought would be a bad experience.

The possibility that patients may have given false answers to certain questions (particularly regarding their private lives) is a limitation of our study. Given that only three of the 750 respondents admitted having a negative experience was considered an optimistic figure considering the conditions in our country.

In conclusion, our findings revealed that age, gravida, previous type of delivery, previous anaesthesia experience, employment status, monthly income level, educational status, and preoperative information related to anaesthesia and its source and presence of panic disorder all had significant effect on anaesthesiachoice. We believe that the choice of regional anaesthesia will be in line with the level that is required in women who at the ideal pregnancy age, that have had no negative experiences of childbirth or anaesthesia, that have a high sociocultural level, that have obtained information about anaesthesia from reliable sources, and that have not been diagnosed with a panic disorder.

\section{Acknowledgement}

This paper is a part of my dissertation "FACTORS AFFECTING ANAESTHESIA PREFERENCES OF THE GRAVID WOMEN WHO ARE TO DELIVER BY CAESAREAN SECTION”, published on 03. 12. 2012.
Abbreviations
CS - caesarean sections
WHO - The World Health Organization
RA - regional anaesthesia
GA - general anaesthesia

\section{DECLARATION OF INTEREST}

The authors declare that there are no conflicts of interest.

\section{Licensing}

This work is licensed under a Creative Commons Attribution 4.0 International (CC BY 4.0) License. 


\title{
Sažetak
}

\section{FAKTORI KOJI UTIČU NA IZBOR ANESTEZIJE KOD TRUDNICA ZA POROĐAJ CARSKIM REZOM}

\author{
Sahinturk Helin, Turhan Cakar Sanem, Can Selvi Ozlem, Yilmaz Abbas Ali, Uysalel Asuman \\ Anesthesiology and ICM Department, Ankara University Faculty of Medicine, Ankara, Turkey \\ Currently working at Anesthesiology and ICM Department, Baskent University Faculty of Medicine, Ankara, Turkey
}

Uvod: Poslednjih godina primećeno je značajno povećanje učestalosti carskih rezova. Iako su povećane u mnogim zemljama, stopa carskih rezova u Turskoj je veća od ciljane. Ovo povećanje učestalosti carskih rezova utiče i na akušersku anesteziju. U ovoj studiji, istražujemo izbor anestezija koje su predviđene za trudnice kod kojih se planira carski rez, kao i stope učestalosti opšte i regionalne anestezije, ali i faktore koji utiču na njihov izbor.

Metode: Upitnik koji se sastojao od 20 pitanja, primenjen je na trudnicama za elektivni carski rez, u periodu između novembra 2011. god. i novembra 2012. god., kako bi se proučila vrsta anestezije koju preferiraju i razlog za njihove izbore. Upitnik je primenjen na trudnice tokom posete, dan pre operacije ili dok su čekale u čekaonici neposredno pre carskog reza.

Rezultati: Naše istraživanje je otkrilo da starost, gravidnost, prethodna vrsta porođaja, prethodno isku-

\section{REFERNCES}

1. WHO. World Health Statistics 2014. Geneva: World Health Organization; 2014.

2. Betran AP, Torloni MR, Zhang J, Ye J, Mikolajczyk R, Deneux-Tharaux $\mathrm{C}$ et al. What is the optimal rate of caesarean section at population level? A systematic review of ecologic studies. Reprod Health. 2015; 12(1):57.

3. Türkiye İstatistik Kurumu web portal. Türkiye İstatistik Kurumu 2016 Verileri, İstatistiklerle Çocuk, 2016. htpp://www.tuik.gov. tr

4. Lim G, Facco FL, Nathan N, Waters JH, Wong CA, Eltzchig HK. A review of the impact of obstetric anaesthesia on maternal and neonatal outcomes. Anesthesiology 2018; 129(1): 192-215.

5. de Vienne CM, Creveuil C, Dreyfus M. Does young maternal age increase the risk of adverse obstetric, fetal and neonatal outcomes: a cohort study. Eur J Obstet Gynecol Reprod Biol. 2009 ;147(2): 151-6.

6. Fall CH, Sachdev HS, Osmond C, Restrepo-Mendez $\mathrm{MC}$, Victora C, Martorell R et al. Association between maternal age at childbirth and child and adult outcomes in the offspring: a prospective study in five low-income and middle-income countries (COHORTS collaboration). Lancet Glob Health. 2015; 3(7): e366-77.

7. Kocamanoğlu IS, Sarıhasan B, Sener B, Tür A, Şahinoğlu H, Sunter T. Sezaryen uygulamalarında uygulanan anestezi yöntemleri ve komplikasyonları: 3552 olgunun retrospektiv de- stvo sa anestezijom, radni status, mesečni nivo prihoda, obrazovni status, prethodno informisanje o anesteziji, izvor informacija i dijagnostikovanje paničnog poremećaja su uticali na odluku o tome koji tip anestezije će koristiti.

Zaključak: Otkrili smo trudnice sa višim stepenom obrazovanja, koje rade i imaju veći nivo mesečnih primanja, preferiraju oblik regionalne anestezije, a razlog leži u tome da imaju više informacija o samim metodama anestezije, češće koriste internet i informacije koje prikupljaju od ljudi oko sebe ne drže kao predrasude protiv regionalne anestezije. Smatramo da kako se nivo obrazovanja bude povećavao u budućnosti, a populacija pacijenata bude postajala sve svesnija, to ce ih uputiti na više istraživanja, a njihove stope preferencija će se menjati.

Ključne reči: Carski rez, izbor anestezije, upitnik.

ğerlendirilmesi. Türkiye Klinikleri J. Med. Sci 2005; 25(6): 810-6.

8. Gülhaş N, Şanlı M, Özgül Ü, Bergeç Z, Durmuş M. Sezaryenlerde Anestezi Yönetimi: Retrospektif Değerlendirme. Journal of Inonu University Medical Faculty. 2012; 19(3): 142-5.

9. Buyukbayrak EE, Kaymaz O, Kars B, Karsıdag KYA, Bektas E, Unal O et al. Caesarean delivery or vaginal birth: Preference of Turkish pregnant women and influencing factors. $\mathrm{J}$ Obstet Gynaecol. 2010; 30(2): 155-8.

10. Fuglenes D, Aas E, Botten G, Qian P, Kristiansen SI. Why do some pregnant women prefer cesarean? The influence of parity, delivery experiences and fear. Am J Obstet Gynecol. 2011; 205(1): 45e1-9.

11. Bukar M, Kwari YD, Moruppa YJ, Ndonya ND. Anaesthesia for caesarean delivery: Choice of technique among antenatal attendees in North-eastern Nigeria. J Obstet Gynaecol. 2010; 30(8): 822-5.

12. Yılmaz AA, Ateş Y. Ağrı Algılanmasında Kadın ve Erkek Farkları. Doktor Dergisi Haziran-Temmuz 2017; 84-8.

13. Adams SS, Eberhard-Gran M, Eskild A. Fear of childbirth and duration of labour: a study of 2206 women with intended vaginal delivery. BJOG 2012; 119(10): 1238-46.

14. Klabbers GA, van Bakel HJA, van den Heuvel MMA, Vingerhoets AJ. Severe fear of childbirth: Its features, assesment, prevalence, determinants, consequences and possible treatments. Psychological Topics 2016; 25(1): 107-27.

Correspondence to/Autor za korespondenciju

Helin Sahinturk, M.D

Baskent University,Faculty of Medicine, Department of Anesthesiology and ICM, Ankara, Turkey

Address: Fevzi Cakmak Caddesi 10.Sokak No:45 Bahcelievler, 06490, Ankara

P: +90 312 2126868/4817, F: +90 3122237333

e-mail: helinsahinturk@yahoo.com 